\title{
Reduction of chromium oxide from slags
}

\author{
J. Gutiérrez-Paredes*, A. Romero-Serrano*, M.A. Hernández*, F. Chávez-Alcalá* \\ and B. Zeifert*
}

\begin{abstract}
Experimental and theoretical work were performed to estimate the effect of slag basicity and amount of reducing agents on the reduction of chromium oxide from the slag which interacted with molten steel at $1,600{ }^{\circ} \mathrm{C}$. The slag system contained $\mathrm{CaO}, \mathrm{MgO}, \mathrm{SiO}_{2}$, $\mathrm{CaF}_{2}$ and $\mathrm{Cr}_{2} \mathrm{O}_{3}$ together with Fe-alloys ( $\mathrm{Fe}-\mathrm{Si}$ and $\mathrm{Fe}-\mathrm{Si}-\mathrm{Mg}$ ). The $\mathrm{CaF}_{2}$ and $\mathrm{MgO}$ contents in the slags were 10 mass $\%$ each; $\mathrm{Cr}_{2} \mathrm{O}_{3}$ was $25 \%$. The amount of the ferroalloys ranged from 12.5 to $50 \mathrm{~g}$ per $100 \mathrm{~g}$ of slag. The $(\mathrm{CaO}+\mathrm{MgO}) / \mathrm{SiO}_{2}$ ratio was held at 1 and 2. The $\mathrm{Cr}$ yield was determined using both $\mathrm{Fe}$-alloys as reducing agents. Some estimations were made to determine the theoretical effect of temperature, slag basicity, $(\mathrm{CaO}+\mathrm{MgO}) / \mathrm{SiO}_{2}$, and amount of reducing agents in the slag on the chromium recovery. The FACT (Facility for the Analysis of Chemical Thermodynamics) computational package is used to determine the equilibrium between the slag and molten steel.
\end{abstract}

Keywords Chromium. Slags. Stainless steel. Reduction.

\section{Reducción de óxidos de cromo contenidos en las escorias}

Resumen

Palabras clave

\begin{abstract}
En el presente trabajo se realiza un estudio teórico y experimental para determinar el efecto de la basicidad de la escoria y la cantidad de agentes reductores sobre la reducción de óxidos de cromo contenidos en la escoria, la cual está en contacto con acero líquido a $1.600^{\circ} \mathrm{C}$. $\mathrm{La}$ escoria se prepara con los reactivos $\mathrm{CaO}, \mathrm{MgO}, \mathrm{SiO}_{2}, \mathrm{CaF}_{2}$ y ferroaleaciones ( $\mathrm{Fe}-\mathrm{Si}$ y Fe-Si-Mg). Los contenidos de $\mathrm{CaF}_{2}$ y $\mathrm{MgO}$ en la escoria son de $10 \%$, cada uno, y el de $\mathrm{Cr}_{2} \mathrm{O}_{3}$ es $25 \%$. La cantidad de la ferroaleación varía de 12,5 a $50 \mathrm{~g}$ por cada $100 \mathrm{~g}$ de escoria. La relación $(\mathrm{CaO}+\mathrm{MgO}) / \mathrm{SiO}_{2}$ tiene los valores de 1 y 2 . Se determina la eficiencia de recuperación de cromo empleando los dos tipos de ferroaleaciones. Se realizaron cálculos para determinar el efecto teórico de la temperatura, la basicidad de la escoria, $(\mathrm{CaO}+\mathrm{MgO}) / \mathrm{SiO}_{2}$, y la cantidad de agentes reductores sobre la reducción de los óxidos de cromo. El sistema de cómputo FACT (Instalación para el Análisis de Termodinámica Química) se empleó para determinar el equilibrio entre la escoria y el acero líquido.
\end{abstract}

Cromo. Escoria. Acero inoxidable. Reducción.

\section{INTRODUCTION}

The slags in the stainless steelmaking process are subjected to both oxidizing conditions during carbon removal and reducing conditions in the final refining stage. The transitional metallic ions of chromium in the slag will respond to the oxygen potential variations by changing the oxidation state. Reduction of chromium oxide from liquid slags is of fundamental importance in the manufacture of chromium alloyed steels. The solubility of chromium oxide or the activity composition relation in the slag directly influences the metallurgical process as a high solubility increases the chromium losses to slag. Since chromium is one of the major constituents of stainless steel, it also represents a large portion of the raw material cost. Consequently, a high chromium recovery is essential for overall economy.

The chromium oxide-containing systems are more complex than other transition metal oxide systems, such as the iron-containing systems, because chromium exists in three valencies, $\mathrm{Cr}^{2+}$, $\mathrm{Cr}^{3+}$ and $\mathrm{Cr}^{6+}$ depending on the oxygen partial pressure, temperature and slag composition ${ }^{[1]}$. It

(*) Dept. of Metallurgical Eng., IPN-ESIQIE, A. Postal 118-431, México D.F. 07051 
was found that divalent and trivalent chromium co-exists in the slags related to ferrochromium and stainless steel production. It has been reported that magnesium-based slags reduce the refractory lining attack due to its own magnesia contribution what it means a real protection of the furnace walls. Additionally, the increase of $\mathrm{MgO}$ content in the slag, decreases the Cr-leaching ${ }^{[2]}$. The behavior of chromium and its oxides has been the subject of studies concerned with equilibrium behavior as well as the mechanisms of chromium reduction, mainly by silicon and magnesium ${ }^{[3]}$.

In this work the experiments were conducted with low alloy steel. The slag was prepared with reagent grade $\mathrm{CaO}, \mathrm{MgO}, \mathrm{SiO}_{2}, \mathrm{CaF}_{2}$ and ferroalloys as reducing agents. The results of this work show the effects of time of process, slag basicity and $\mathrm{Fe}$-alloy additions in slag on the chromium content in steel.

\section{MATERIALS AND EXPERIMENTAL PROCEDURE}

The experiments were conducted in $5 \mathrm{~kg}$ of molten low alloy steel with the standard composition: 0.06 mass \% C, $0.20 \% \mathrm{Si}, 0.32 \% \mathrm{Mn}$ and $0.035 \% \mathrm{~S}$ at $1,600 \pm 20^{\circ} \mathrm{C}$. The slag was prepared with laboratory reagent-grade oxides $\left(\mathrm{CaO}, \mathrm{MgO}, \mathrm{SiO}_{2}, \mathrm{Cr}_{2} \mathrm{O}_{3}\right)$ and $\mathrm{CaF}_{2}$. Some experiments were carried out with the ferroalloy ( $\mathrm{Fe}-\mathrm{Si}-\mathrm{Mg}$ ) with $44 \% \mathrm{Si}$ and $9 \% \mathrm{Mg}$, as reducing agent; and other with the ferroalloy $(\mathrm{Fe}-\mathrm{Si})$ with $75 \% \mathrm{Si}$. The $\mathrm{CaF}_{2}$ and $\mathrm{MgO}$ contents in slag were 10 mass \% each, and $\mathrm{Cr}_{2} \mathrm{O}_{3}$ was $25 \%$. These materials were crushed and ground into powder and the final size was between 37 and $45 \mathrm{~mm}$. The amounts of ferroalloys were $12.5,25$ and $50 \mathrm{~g}$ per 100 $\mathrm{g}$ of slag, which represent $12.5,25$ and $50 \%$ of the mass of oxide slag. The $(\mathrm{CaO}+\mathrm{MgO}) / \mathrm{SiO}_{2}$ ratio was held at 1 and 2. Two top addition of $200 \mathrm{~g}$ of slag were carried out in the experiments.

The experimental apparatus is shown schematically in figure 1. A induction furnace with $\mathrm{Al}_{2} \mathrm{O}_{3}$-based refractory was used. Melt temperature was measured along the experiments by the immersion of an R-Type thermocouple (Pt/Pt-13\% $\mathrm{Rh})$. It must be stressed that the Fe-alloy was mixed with the oxide species of the slag before the experiments. The top of the furnace was covered with a ceramic plate and nitrogen gas was introduced from the top of the furnace at a flow rate of $6 \mathrm{~L} \mathrm{~min}^{-1}$ in order to maintain an inert atmosphere above the system.

After being attained $1,600^{\circ} \mathrm{C}$, the initial metal sample was taken into a small silica tube by suction.

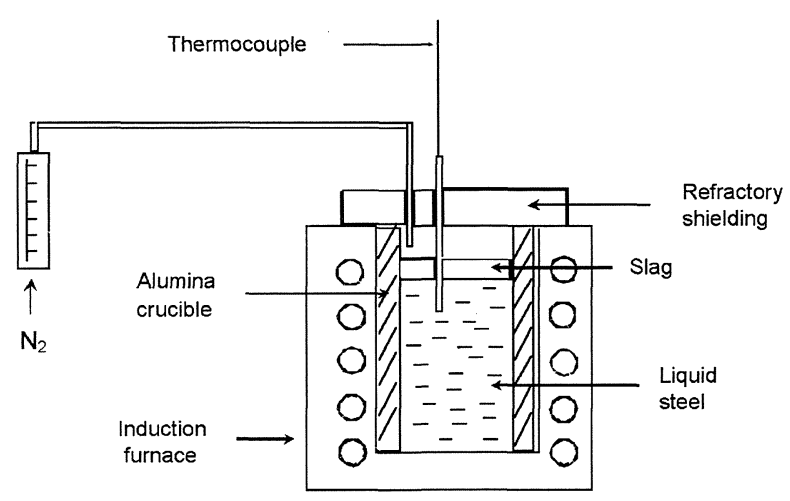

Figure 1. Experimental furnace apparatus for chromium oxide reduction from slag.

Figura 1. Equipo experimental para la reducción del óxido de cromo a partir de la escoria.

Then the first slag was added, and this moment was taken as the starting time of the reaction. Subsequently several metal samples were taken at 5 min intervals. After $15 \mathrm{~min}$ the first slag was removed, then the second slag was added and samples were again taken at $5 \mathrm{~min}$ intervals.

The reaction time considered in the experiments does not enable the system to reach the equilibrium state, however, some estimations have been made to determine the theoretical effect of temperature and kind of reducing agents in the slag. The FACT computational thermodynamic package $^{[4]}$ is used to determine the equilibrium between the slag and molten steel.

\section{RESULTS AND DISCUSSION}

\subsection{Equilibrium calculations}

Thompson et. al. ${ }^{[4]}$ have developed a thermodynamic database available in the software FACT (Facility for the Analysis of Chemical Thermodynamics). The software accesses a user-database of species in solution allowing to determine the equilibrium composition of a multiphase and multicomponent system at given temperature, pressure and initial composition. In general, this program uses the method of minimization of free energy to determine the concentrations of each phase in equilibrium. This software uses the unified interaction parameter proposed by Bale and Pelton $^{[5]}$ for the molten steel and the quasichemical approximation ${ }^{[6]}$ for the slag. The output from the calculation gives the composition for stable solution phases (liquid steel and slag phase). 
For given constraints (such as fixed temperature, pressure and overall concentration) the free energy minimization algorithm used in FACT finds the set of mole numbers of each species, which globally minimizes the free energy function. The equilibrium computations were performed to analyze the effect of both temperature and kind of reducing element $(\mathrm{Mg}, \mathrm{Al}, \mathrm{Ca}$ and $\mathrm{Si})$.

The equilibrium computations were performed for a system with $120 \mathrm{~g}$ of low carbon steel $(0.06 \%$ $\mathrm{C}, 0.20 \% \mathrm{Si}, 0.32 \% \mathrm{Mn}$ and $0.035 \% \mathrm{~S}), 20 \mathrm{~g}$ of slag and $3 \mathrm{~g}$ of reducing element at temperatures from 1,500 to $1,800^{\circ} \mathrm{C}$. The slag composition used to simulate the chromium reduction process was 10 $\% \mathrm{CaF}_{2}, \quad 10 \% \mathrm{MgO}, 25 \% \mathrm{Cr}_{2} \mathrm{O}_{3}$ and $(\mathrm{CaO}+\mathrm{MgO}) / \mathrm{SiO}_{2}=2$.

Figure 2 presents the equilibrium results of the effect of temperature and kind of reducing agent on the mass \% $\mathrm{Cr}$ in steel. As far as the thermodynamic analysis concerns, magnesium is the best element to reduce the chromium oxides from the slag. The effect of temperature on the chromium recovery is negligible except when silicon is used; in such a case, the higher the temperature the lower efficiency of silicon as reducing agent.

\subsection{Experimental results}

In figure 3 the chromium content in liquid steel is shown as the function of processing time and amount of $\mathrm{Fe}$-alloy for two slag basicities, $(\mathrm{CaO}+\mathrm{MgO}) / \mathrm{SiO}_{2}, 1$ and 2. The Fe-alloy used in this case was (Fe-Si-Mg) with $44 \% \mathrm{Si}$ and $9 \% \mathrm{Mg}$.

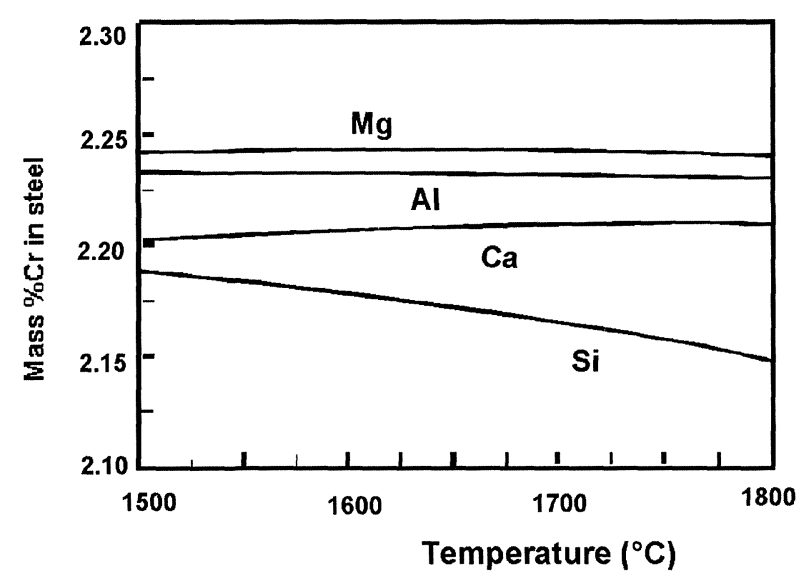

Figure 2. Calculated effect of temperature and kind of reducing elements on the chromium content in steel.

Figura 2. Cálculo del efecto de la temperatura y tipo de agentes reductores sobre el contenido de cromo en el acero.
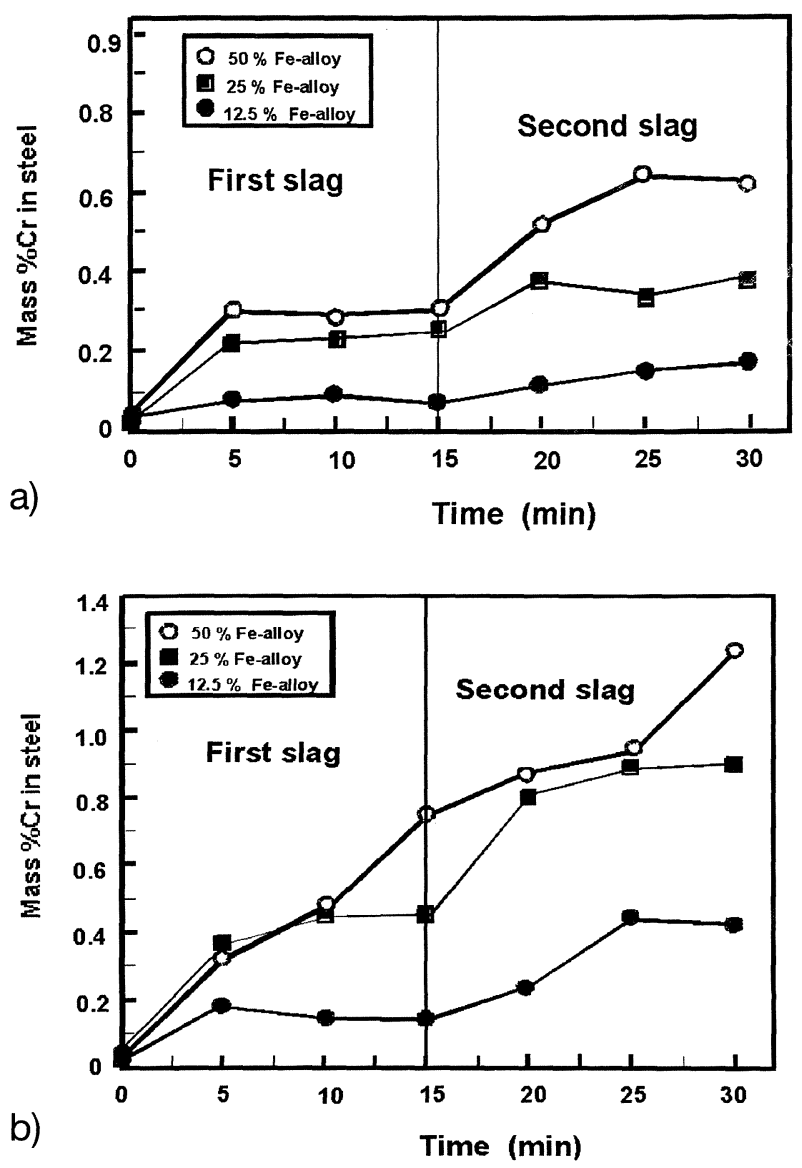

Figure 3. Effect of processing time, reducing agent $(\mathrm{Fe}-\mathrm{Si}-\mathrm{Mg})$ and slag basicity on the chromium content in steel.

Figura 3. Efecto del tiempo, agente reductor (Fe-Si-Mg) y basicidad de la escoria sobre el contenido de cromo en el acero.

As expected, the chromium recovery from the slag increases as a function of the amount of the reducing agent in the system. It is also clear that the chromium concentration in steel increases with the slag basicity. This is in agreement with the results of Okabe et al. ${ }^{[7]}$, where the distribution ratio $\left(\mathrm{L}_{\mathrm{Cr}}=\mathrm{Cr}_{\text {slag }} / \mathrm{Cr}_{\text {metal }}\right)$ between slag and metal decreases with increasing slag basicity. This is partially due to the direct effect of basicity on the activity coefficients of chromium oxides $(\mathrm{CrO}$ and $\mathrm{Cr}_{2} \mathrm{O}_{3}$ ), as was reported by Morita and Sano ${ }^{[8]}$. In addition, as far as the amount of the elements in this Fe-alloy is concerned, silicon is the main reducing agent followed by magnesium. Therefore, chromium is recovered from the slag by reducing its oxide with silicon and magnesium according to the following reactions:

$$
\begin{aligned}
2(\mathrm{CrO})+\mathrm{Si} & =2[\mathrm{Cr}]+\left(\mathrm{SiO}_{2}\right) \\
(\mathrm{CrO})+\mathrm{Mg} & =[\mathrm{Cr}]+(\mathrm{MgO})
\end{aligned}
$$


The higher the slag basicity and higher the silicon content in the system, the lower is the equilibrium slag/metal distribution of chromium, i.e. the greater the chromium recovery from the slag. As can be seen in figure 3 , the chromium recovery removal was rapid at early stages of the process with each slag and almost ceased at the end of the experiments, pointing that, under the experimental conditions tested, larger reaction times might not remarkably improve the chromium recovery from the slag.

In order to the compare the efficiency of magnesium and silicon as reducing agents for chromium oxides we carried out other trials with similar experimental conditions but in this case the $\mathrm{Fe}$-alloy used contained $75 \% \mathrm{Si}$. The slag basicity was $(\mathrm{CaO}+\mathrm{MgO}) / \mathrm{SiO}_{2}=2$. The results are shown in figure 4.

A comparison of the chromium content in steel using $\mathrm{Fe}-45 \% \mathrm{Si}-9 \% \mathrm{Mg}$ (figure $3 \mathrm{~b}$ ) and $\mathrm{Fe}-75 \%$ $\mathrm{Si}$ (figure 4) shows that the chromium recovery was slightly better with the latter Fe-alloy. However, it is important to remark that the second Fe-alloy contains about $30 \%$ more of silicon than the first one. That means that the $9 \%$ magnesium content in the reducing agent almost produced the same effect of the $30 \%$ of silicon. The maximum chromium content expected in the molten steel was $1.37 \%$. Therefore, the maximum chromium yield was about $92 \%$ with $\mathrm{Fe}-\mathrm{Si}-\mathrm{Mg}$ and $98 \%$ with $\mathrm{Fe}$-Si. In both cases the slag basicity was 2 with 50 $\%$ of Fe-alloy.

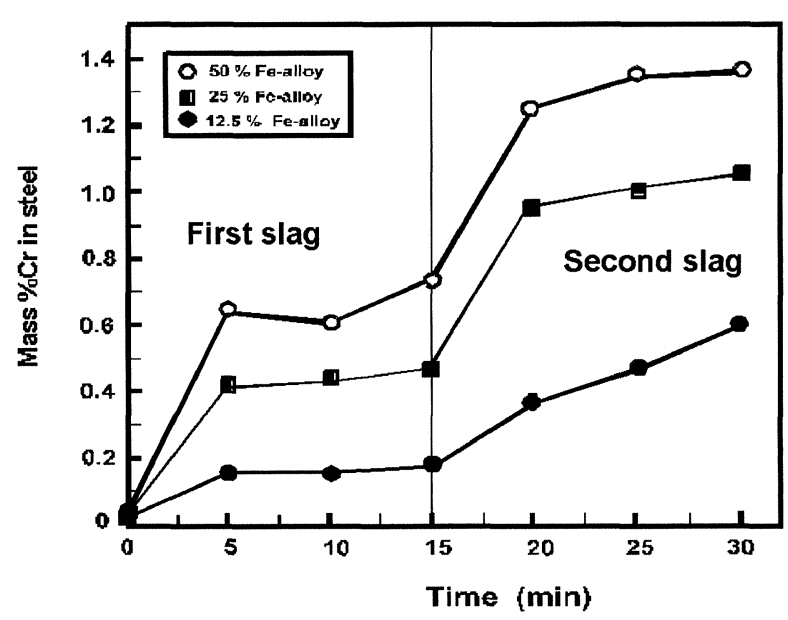

Figure 4. Effect of processing time and reducing agent (Fe-Si) on the $\mathrm{Cr}$ content in steel. $(\mathrm{CaO}+\mathrm{MgO}) / \mathrm{SiO}_{2}=2$.

Figura 4. Efecto del tiempo y agente reductor (Fe-Si) sobre el contenido de $\mathrm{Cr}$ en el acero. $(\mathrm{CaO}+\mathrm{MgO}) / \mathrm{SiO}_{2}=a 2$.

\section{CONCLUSIONS}

In order to understand the effect of process parameters on the reduction of chromium oxides from slags theoretical and experimental studies were performed. The following results were obtained:

- The efficiency of chromium reducing agents increases in the order: silicon, calcium, aluminum and magnesium.

- The chromium yield increases with slag basicity and amount of reducing agents.

- The maximum chromium yield was about 92 percent with $\mathrm{Fe}-45 \% \mathrm{Si}-9 \% \mathrm{Mg}$ and 98 percent with $\mathrm{Fe}-75 \% \mathrm{Si}$. That means that the reducing effect of $\mathrm{Mg}$ was much better than that of silicon.

- The chromium recovery was rapid at early stages of the process with each slag and almost ceased at the end of the experiments, pointing that, under the experimental conditions tested, larger reaction times might not remarkably improve the process.

\section{Acknowledgements}

The authors wish to thank the Institutions CONACyT, SNI, COFAA and Instituto Politécnico Nacional for their permanent assistance to the Process Metallurgy Group at ESIQIE-Department of Metallurgy.

\section{REFERENCES}

[1] Y. XiaO, L. Holappa and M.A. Reuter, Metall. Trans. B 33 (2002) 595-603.

[2] M. GORNERUP and A.K. LAHIRI, Ironmaking and Steelmaking 25 (1998) 317-322.

[3] L. Perdomo-Glez, R. Quntana-Puchol, A. CruzCrespo, J. Castellaos-Estupiñan, L.L. GarCía-SÁnChez, A. Formoso And A. Cores, Rev. Metal. Madrid 39 (2003) 268-278.

[4] W.T. Thompson, C.W. BAle and A.D. Pelton, FACT SageFacility for the Analysis of Chemical Thermodynamics, 2001, User's Manual.

[5] C.W. Bale and A.D. Pelton, Metall. Trans. A 21 (1990) 1997-2002.

[6] A.D. Pelton and M. Blander, Metall. Trans. B 17 (1986) 805-815.

[7] Y. OKabe, I. Tajima and K. ITO, Metall. Trans. B 29 (1998) 131-136.

[8] K. Morita and N. Sano, Proc. Process Technol. Conf., Orlando Florida, 2000 pp. 1097-1107.

Rev. Metal. Madrid Vol. Extr. (2005) 443-446 